\title{
Removal of Toxic Heavy Metals from Contaminated Aqueous Solutions Using Seaweeds: A Review
}

\author{
Edward Hingha Foday Jr ${ }^{1,2,3}$ (D) Bai Bo ${ }^{1,2,4,5, *}$ and Xiaohui Xu ${ }^{1,2}$ \\ 1 Key Laboratory of Subsurface Hydrology and Ecological Effects in Arid Region of the Ministry of Education, \\ Chang'an University, Xi'an 710054, China; hinghaja@gmail.com (E.H.F.J.); xx4@princeton.edu (X.X.) \\ 2 Department of Environmental Engineering, School of Water and Environment, Chang'an University, \\ Xi'an 710054, China \\ 3 Faculty of Education, Eastern Technical University of Sierra Leone, Combema Road, \\ Kenema City 00232, Sierra Leone \\ 4 Key Laboratory of Tibetan Medicine Research, Northwest Institute of Plateau Biology, \\ Chinese Academy of Sciences, Xining 810008, China \\ 5 Qinghai Provincial Key Laboratory of Tibetan Medicine Research, Xining 810001, China \\ * Correspondence: baibochina@163.com
}

check for updates

Citation: Foday Jr, E.H.; Bo, B.; Xu, X. Removal of Toxic Heavy Metals from Contaminated Aqueous Solutions Using Seaweeds: A Review. Sustainability 2021, 13, 12311. https:/ / doi.org/10.3390/su132112311

Academic Editors:

Avelino Núñez-Delgado,

Zhien Zhang, Elza Bontempi,

Mario Coccia, Marco Race,

Yaoyu Zhou and Marc A. Rosen

Received: 20 September 2021

Accepted: 5 November 2021

Published: 8 November 2021

Publisher's Note: MDPI stays neutral with regard to jurisdictional claims in published maps and institutional affiliations.

Copyright: (c) 2021 by the authors. Licensee MDPI, Basel, Switzerland. This article is an open access article distributed under the terms and conditions of the Creative Commons Attribution (CC BY) license (https:// creativecommons.org/licenses/by/ $4.0 /)$.

\begin{abstract}
Heavy metal contamination affects lives with concomitant environmental pollution, and seaweed has emerged as a remedy with the ability to save the ecosystem, due to its eco-friendliness, affordability, availability, and effective metal ion removal rate. Heavy metals are intrinsic toxicants that are known to induce damage to multiple organs, especially when subjected to excess exposure. With respect to these growing concerns, this review presents the preferred sorption material among the many natural sorption materials. The use of seaweeds to treat contaminated solutions has demonstrated outstanding results when compared to other materials. The sorption of metal ions using dead seaweed biomass offers a comparative advantage over other natural sorption materials. This article summarizes the impact of heavy metals on the environment, and why dead seaweed biomass is regarded as the leading remediation material among the available materials. This article also showcases the biosorption mechanism of dead seaweed biomass and its effectiveness as a useful, cheap, and affordable bioremediation material.
\end{abstract}

Keywords: heavy metals; seaweed; biosorption; aqueous solution; remediation

\section{Introduction}

The severity of heavy metal pollution cannot be over-emphasized, as it has become a universal issue in recent years. The effects of heavy metals in the environment are harmful due to their high toxicity. Their release into the environment occurs as a result of various natural and anthropogenic activities. Unfortunately, most of these heavy metals, whether generated from human activities or nature, constantly undermine the existence and health of environmental resources. The toxicity, persistence, and non-biodegradable nature of these metal ions make them a threat to the environment $[1,2]$. These heavy metals are known to cause multiple and complicated health problems such as brain and lung damage, cancer, nausea, and vomiting [3,4]. Seaweed, also known as marine algae, serves as one of the major leading biosorption materials for the treatment of heavy metals [5]. Seaweed produces a variety of compounds such as xanthophylls, chlorophyll, carotenoids, vitamins, fatty acids, amino acids as well as antioxidants (such as halogenated compounds, alkaloids, and polyphenols), and polysaccharides (such as agar, alginate, carrageenan, proteoglycans, galactosyl glycerol, laminarin, rhamnan sulfate, and fucoidan) [6]. The presence of alginate in the seaweed makes it an effective eluted material for metal ion removal. Alginate, as well as fucoidan, has a high sorption capacity, which can mainly be attributed to polysaccharides found in the cell walls. The carboxylic and sulfonic acid functional groups are more active in the ion exchange process, and polysaccharides are 
responsible for these functional groups [5,7]. On the whole, seaweed has proven to be one of the most outstanding and important biosorption materials for the remediation of metal ions. Its low cost, availability, and eco-friendliness, coupled with its high metal ion uptake capability, make it an ideal biosorption material compared to other sorption materials [6,8]. In this review, dead seaweed biomass is of particular interest, and because of the scant knowledge regarding its usefulness and biosorption mechanism, we seek to throw light on the importance of dead seaweed biomass as a sorption material and to summarize its biosorption mechanism. This review also pinpoints the toxic effects of heavy metals on environmental resources, as well as comparing dead seaweed biomass with other natural sorption materials in terms of heavy metal removal.

\section{Heavy Metal Contamination in Water}

Water is a universal solvent needed by all living organisms and is also good at dissolving both organic and inorganic compounds. Water resources are critically affected by heavy metal contamination, and this has seriously altered the aquatic ecosystem [9]. On a large scale, aquatic ecosystems are contaminated by heavy metals from industrial effluent, domestic sewage, and agricultural runoff [10]. Most rivers, streams, and lakes are polluted through erosion and leaching, while atmospheric deposition, metal corrosion, sediment resuspension, and metal evaporation are some of the ways the environment gets polluted [11,12]. The non-biodegradable character of heavy metals and their persistence in the environment have led to bioaccumulation through the food chain, leading to complicated health issues and environmental pollution [13]. The term heavy metals refer to metals and metalloids whose mass is over $5 \mathrm{~g} /$ cubic centimeters $\left(\mathrm{g} / \mathrm{cm}^{3}\right)$ and are naturally occurring elements commonly found on earth [14]. They can be regarded as trace elements due to their trace concentrations in the environment. The set of environmental matrices for metal ion concentrations range from zero (0) ppb to ten $(10) \mathrm{ppb}[15,16]$. Anthropogenic and natural activities such as mining, fossil fuel combustion, agriculture, volcanic eruptions, earthquakes, weathering of rocks, and industrial activity are the main causes of environmental contamination [17]. Direct contact with these heavy metals either through inhalation or ingestion poses serious health threats such as teratogenesis, cancer, and internal disorders [18]. Cadmium (Cd), Chromium (Cr), Lead (Pb), Mercury ( $\mathrm{Hg}$ ), and Arsenic (As) were identified by Tchounwou and team [16] as the most toxic heavy metals, and have been placed under the category "priority metals", which means they are metals of public concern, due to their toxic nature. These aforementioned metal ions are innately toxic and are capable of inducing damage to multiple organs even at minimal exposure levels. Reactive oxygen species (ROS) together with oxidative stress (OS) play key roles in the carcinogenic and toxic nature of these metal ions [16]. Zinc (Zn), Copper $(\mathrm{Cu})$, Molybdenum (Mo), and several other metals have also been considered essential elements because they assist in biochemical reactions, although excess exposure above the required threshold can impair human health [19]. Against this background, international institutions like the United States Environmental Protection Agency (USEPA), the World Health Organization (WHO), the European Union (EU), etc. have set acceptable thresholds referred to as Maximum Contaminant Levels (MCLs). Table 1 shows the internationally accepted thresholds of metal ion concentrations in drinking water. 
Table 1. Accepted thresholds of toxic metal ions in drinking water.

\begin{tabular}{|c|c|c|c|c|c|}
\hline \multicolumn{6}{|c|}{ Drinking Water Acceptable Standards in $\left(\mathrm{mg} \mathrm{L}^{-1}\right)$} \\
\hline Metals & WHO [20] & USEPA [21] & EU Standard [22] & MEE-China [23] & DWI-UK [24] \\
\hline Nickel (Ni) & 0.07 & - & 0.020 & 0.000 & 0.02 \\
\hline Lead $(\mathrm{Pb})$ & 0.01 & 0.015 & 0.005 & 0.010 & 0.01 \\
\hline Zinc $(\mathrm{Zn})$ & - & 5.0 & - & 0.05 & - \\
\hline Copper $(\mathrm{Cu})$ & 2.0 & 1.0 & 2.000 & 1.000 & 2.0 \\
\hline Cadmium (Cd) & 0.003 & 0.005 & 0.005 & 0.005 & 0.005 \\
\hline Mercury (Hg) & 0.006 & 0.002 & 0.001 & 0.00005 & 0.001 \\
\hline Arsenic (As) & 0.01 & 0.010 & 0.01 & 0.050 & 0.01 \\
\hline Chromium (Cr) & 0.05 & 0.100 & 0.025 & 0.050 & 0.05 \\
\hline Antimony & 0.02 & - & 0.01 & - & 0.005 \\
\hline Bromate & 0.01 & - & 0.01 & - & 0.01 \\
\hline Uranium & 0.03 & 0.03 & 0.03 & - & - \\
\hline
\end{tabular}

The contamination of water bodies normally happens through leaching, erosion, wind, and other environmental means, thereby leading to negative health implications and risk to the ecosystem. Heavy metal pollution leaves a negative blueprint on the environment and people's lives. As shown in Figures 1 and 2, natural and anthropogenic sources are the known sources for heavy metal contamination. The natural sources for these toxic metals include volcanic eruptions, forest fires, biogenic sources, and the weathering of rock [25], while industrial estates, automobile exhaust, the spraying of insecticide, agricultural activities, transportation, and mining are the main anthropogenic sources of heavy metals pollution [26].

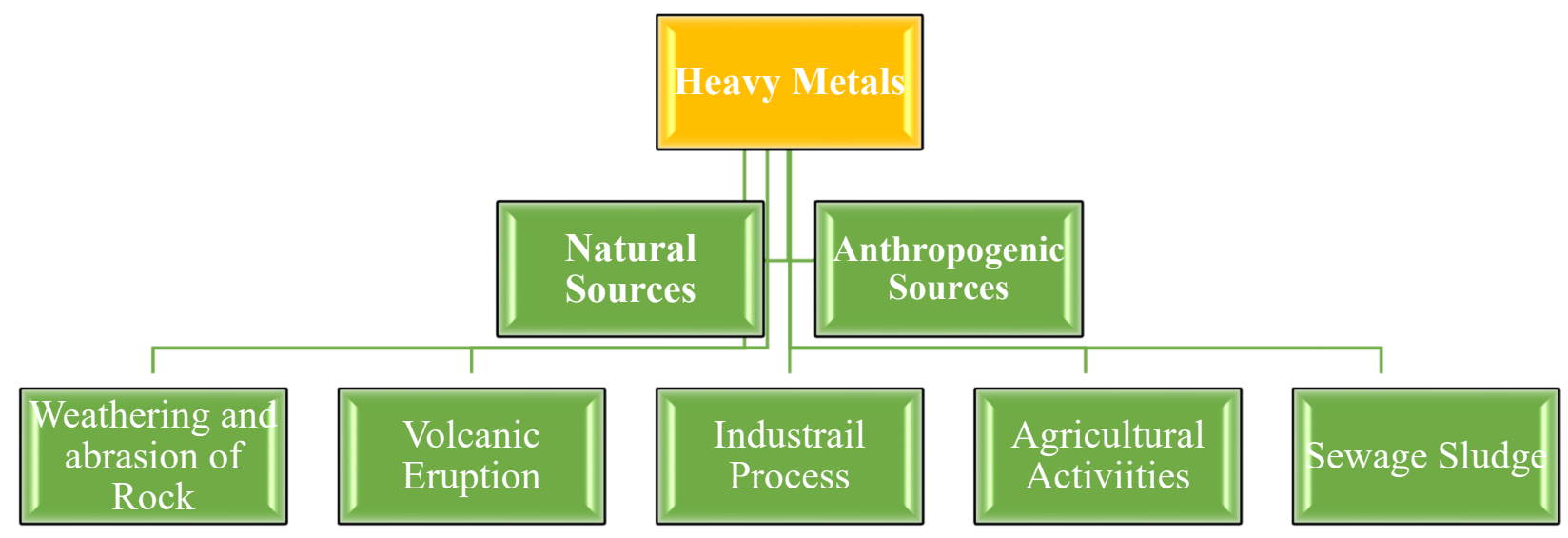

Figure 1. Categories of heavy metal sources.

As seen in Figure 3 below, topsoil and underground water are normally polluted by industrial activities, agricultural activities, weathering, volcanic eruptions, and other biogenic activities. The water bodies become contaminated as the topsoil is washed into them by either erosion, leaching, or landfill leakage. In turn, flora and fauna are affected as the polluted water bodies are consumed and accumulated into their systems, tissues, and organs. Human beings, on the receiving end, are exposed to multiple risks of biochemical disorder or organ failures following the ingestion of contaminated plants and animals. 


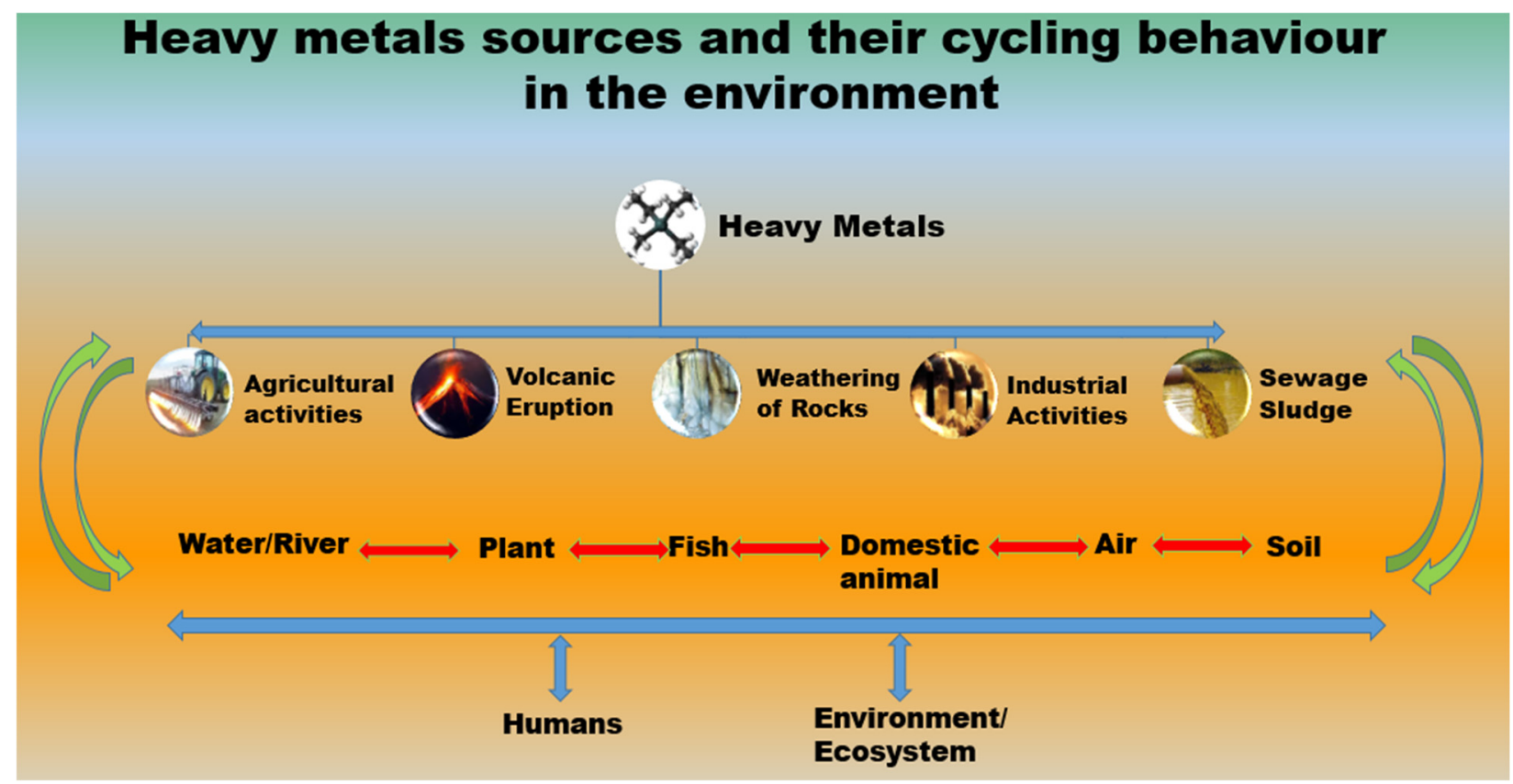

Figure 2. Sources of heavy metals.

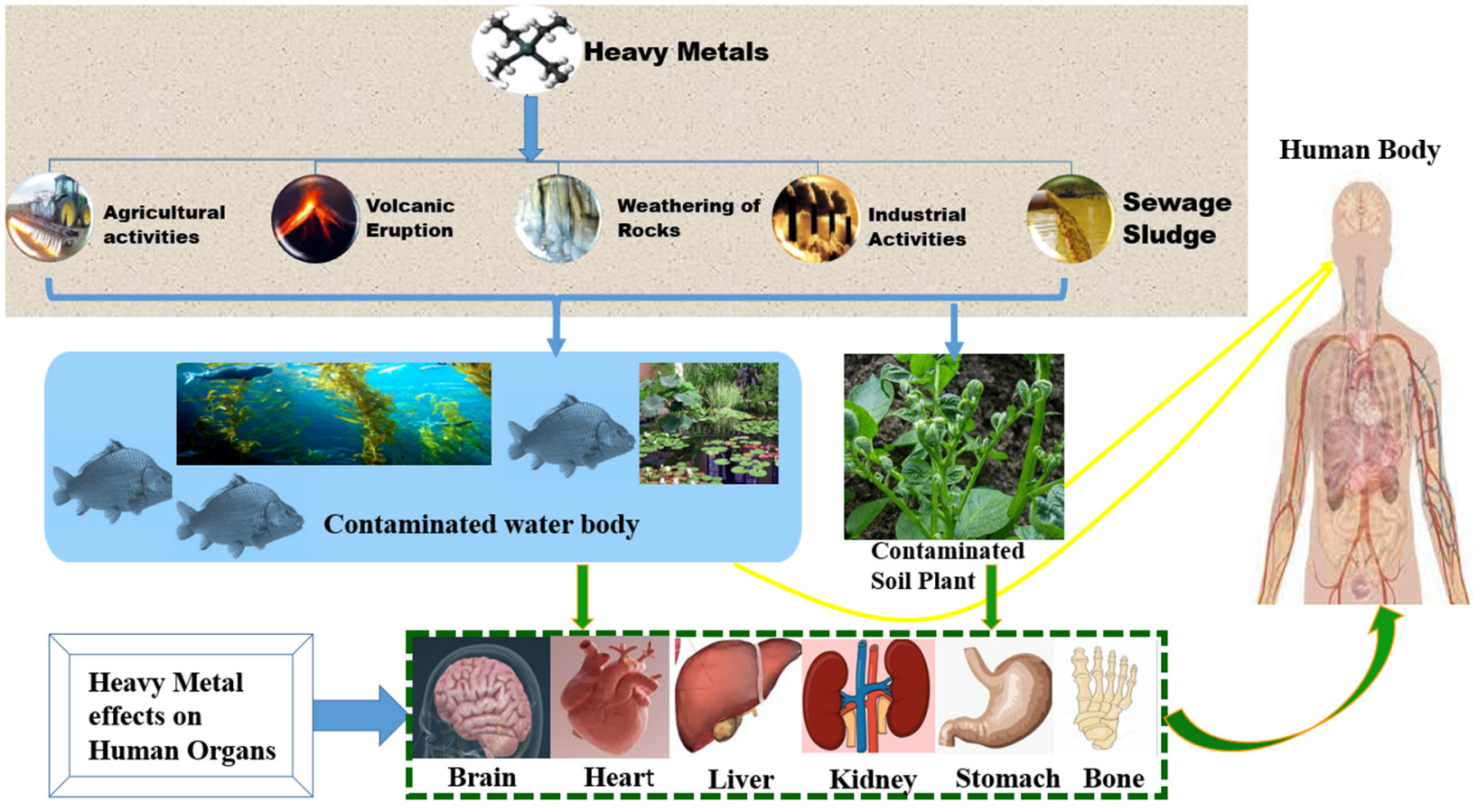

Figure 3. Heavy metal contamination in water.

\section{Structure and Classification of Seaweed}

Seaweed does not have roots, but rather has holdfasts that anchor the seaweed to the bottom of the sea or ocean. These root-like holdfasts are composed of many finger-like components known as Haptera and are supported by a stalk or stem called a Stipe. The structure of the stem or stipe can be hard, filled with gas, soft or flexible, short, or long, and in some cases, they may be completely absent depending on the type of seaweed [27]. These stipes or stem-like structures are either filled with gas or empty. These are referred to as pneumatocysts, while the entire body of the seaweed is referred to as the thallus. Seaweed has leaves called blades, which assist in photosynthesis, although some seaweed 
species have only a single leaf, while others have many leaves. Figure 4 below shows the physical structure of seaweed.

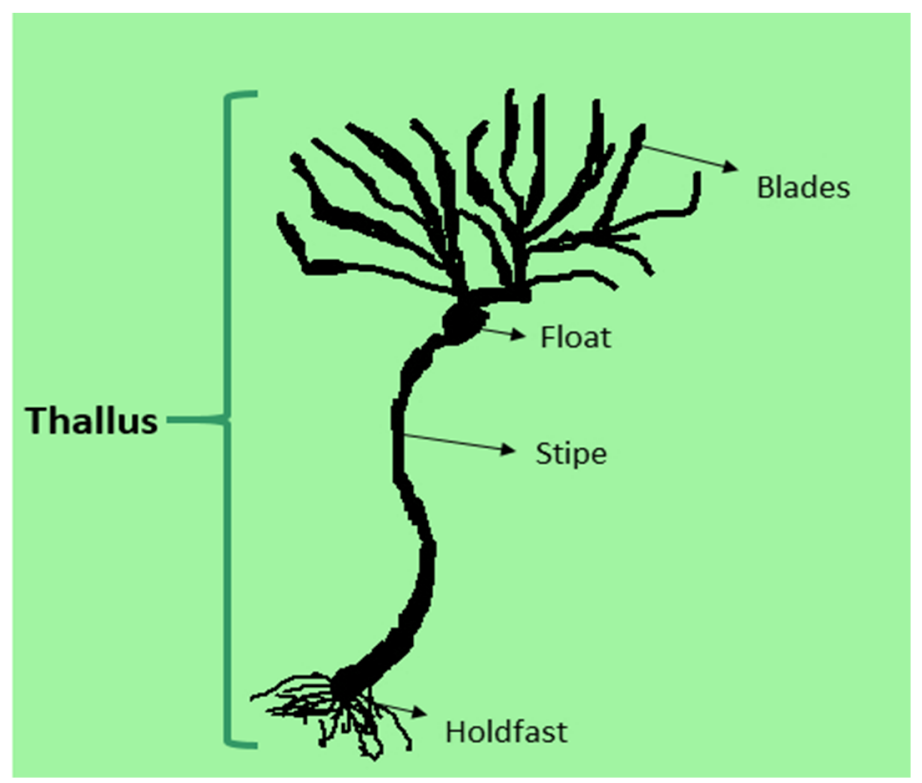

Figure 4. Structure of seaweed.

Seaweed is divided into three (3) main groups based on color characterization, namely: Brown (Phaeophyceae), Red (Rhodophyceae), and Green (Chlorophyceae) seaweeds [28]. Brown algae (Phaeophyta) have various physical appearances either in crust or filament form. Brown algae are multicellular and contain chlorophyll, which aids in photosynthesis, with fucoxanthin being the dominant pigment. Physically, brown algae can range from a large size (Kelp) of about $60 \mathrm{~m}$ long to as small as $60 \mathrm{~cm}$ [29]. Red algae (Rhodophyta) have chlorophyll in which phycocyanin and phycoerythrin are the dominant pigments responsible for red coloration. Red seaweeds are normally not actually red, but brownishred or purple. Physically, red algae are smaller than brown algae in length [30]. Green seaweeds (chlorophyte) have chlorophyll, but with no dominant pigment justifying their green coloration; therefore, green seaweed is generally green. It is smaller in size than both red and brown seaweeds [5,31].

We further characterized seaweeds based on both their physical and chemical compositions as shown in Table 2. The alginate and the intercellular substance of the brown algae have high divalent cation uptakes. The cell walls of brown seaweeds are composed of cellulose, alginic acid, and polysaccharides, with alginates and sulfate being the dominant active groups [7]. The cell wall of red algae contains cellulose, but their biosorption capabilities can largely be attributed to sulfated polysaccharides made up of galactans. Similarly, the cell wall of the green algae contains cellulose with hydroxyl-proline glucosides; xylans and mannans are the main functional groups during biosorption [32,33]. 
Table 2. Characteristics of Seaweed.

\begin{tabular}{|c|c|c|c|c|c|}
\hline $\begin{array}{l}\text { Common Name } \\
\text { (Phylum) }\end{array}$ & Body Form & Size & Pigments & $\begin{array}{l}\text { Colour } \\
\text { Composition }\end{array}$ & Cell Walls \\
\hline $\begin{array}{l}\text { Brown algae } \\
\text { (Phaeophyta) }\end{array}$ & Multicellular & $60 \mathrm{~cm}-60 \mathrm{~m}$ & $\begin{array}{l}\text { Chlorophyll, } \\
\text { Fucoxanthin, and } \\
\text { several other } \\
\text { xanthophylls }\end{array}$ & $\begin{array}{l}\text { Golden-brown, } \\
\text { Greenish-brown }\end{array}$ & $\begin{array}{l}\text { Cellulose, Alginate, } \\
\text { Fucoidan }\end{array}$ \\
\hline $\begin{array}{c}\text { Red algae } \\
\text { (Rhodophyta) }\end{array}$ & Multicellular & $50 \mathrm{~cm}-2 \mathrm{~m}$ & $\begin{array}{c}\text { Chlorophyll, } \\
\text { Phycocyanin, } \\
\text { Phycoerythrin, and } \\
\text { several xanthophylls }\end{array}$ & $\begin{array}{l}\text { Brownish red, } \\
\text { Purple }\end{array}$ & $\begin{array}{l}\text { Cellulose, Xylans, } \\
\text { Galactans }\end{array}$ \\
\hline $\begin{array}{l}\text { Green algae } \\
\text { (Chlorophyta) }\end{array}$ & $\begin{array}{l}\text { Unicellular, } \\
\text { Colonial, } \\
\text { Filamentous, } \\
\text { Multicellular }\end{array}$ & $1-1000 \mu \mathrm{m}$ & $\begin{array}{l}\text { a and b Chlorophyll and } \\
\text { several xanthophylls }\end{array}$ & Green & $\begin{array}{c}\text { Cellulose Hydroxyl } \\
\text {-proline glucosides } \\
\beta \text {-xylans, } \\
\beta \text {-mannans }\end{array}$ \\
\hline
\end{tabular}

\subsection{Seaweed: Metal Ion Biosorption Material}

The treatment of contaminated solutions has been a burden to engineers and scientists over the years. Recently, seaweed has been proven to be more effective than other natural sorption materials. Some of the other natural sorption materials that have been used to elute metal ions are discussed in the next subsection. Remediation of aqueous solution from metal ions is of serious concern to environmentalists, considering the threat it poses to the purity of the natural environment [34]. The non-biodegradability, carcinogenicity, and toxicity of heavy metals make them harmful, and treatment of these heavy metals is essential [35]. Sorption has been proven to be a sustainable and effective method for treating heavy metals in aqueous solutions using natural biomass [36]. Based on these outstanding results, seaweed has emerged as the leading material, with a high rate of metal ion removal. The biosorption method is one of the simplest, cheapest, and most eco-friendly methods, and requires little or no nutrient addition. The effectiveness and efficiency of treatments for heavy metals are directly related to the type of sorbent used [37]. In short, the remediation of heavy metals using seaweed offers a more reliable, cheaper, and more effective means of heavy metal removal from aqueous solutions than the previous methods. Various mechanisms of seaweed biomass (electrostatic interaction, ion exchange, and complex formation) have been used in the biosorption process of heavy metals, and ion exchange has been widely used and is considered the most important among the list of mechanisms [38,39]. The cell walls of the algae possess polysaccharides and protein, which serve as binding sites for metal ion uptake [40]. There are several factors responsible for the sorption capability of a seaweed cell surface; among these factors are accessibility of binding groups for metal ions, the affinity constants of the metal with the functional group, the chemical state of these sites, the number of functional groups in the algae matrix, and the coordination number of the metal ion to be sorbed [41]. The metal biosorption ability of seaweed varies because of the heterogeneity of their respective cell wall composition. For example, as seen in Table 3, brown, green, and red algae have high affinities for lead $(\mathrm{Pb})$, copper $(\mathrm{Cu})$, and cobalt $(\mathrm{Co})$, respectively [7]. Physical or chemical treatment can enhance heavy metal uptake by seaweed, and the cell wall surface is modified, thereby providing additional binding sites for biosorption [7,42]. The physical treatment includes freezing, crushing, heating, and drying, as these increase the surface area on which biosorption can be achieved [42]. The most common seaweed pretreatments are glutaraldehyde, calciumchloride $\left(\mathrm{CaCl}_{2}\right)$, formaldehyde, sodium hydroxide $(\mathrm{NaOH})$, and hydrogen-chloride $(\mathrm{HCl})$. Pretreatment with calcium-chloride $(\mathrm{CaCl} 2)$ enhances calcium binding with alginate, which plays a pivotal role in ion exchange [43]. The crosslinking bond between hydroxyl and amino group is strengthened by formaldehyde and glutaraldehyde [44]. The electrostatic interactions of metal ion cations are increased by sodium hydroxide $(\mathrm{NaOH})$, while at the same time providing optimal conditions for ion exchange, while hydrogen-chloride 
$(\mathrm{HCl})$ dissolves the polysaccharides of the cell wall and also replaces light metal ions with a proton, thereby increasing the biosorption binding sites [7]. It is in this regard that we aim to showcase the comparative advantages of seaweed over other sorption materials in the removal of heavy metals.

Table 3. Different algae species for heavy metal removal.

\begin{tabular}{|c|c|c|c|c|}
\hline Species of Algae & Metal Ions & qmax (mmol/g) & $\mathrm{pH}$ & References \\
\hline \multicolumn{5}{|c|}{ Green Algae } \\
\hline Ulva lactuca & \multirow{9}{*}{$\mathrm{Pb}(\mathrm{II})$} & 0.61 & 4.5 & [45] \\
\hline Cladophora glomerata & & 0.35 & 4.5 & [45] \\
\hline Ulva sp. & & 1.46 & 5.0 & [33] \\
\hline Codium vermilara & & 0.30 & 5.0 & [46] \\
\hline Spirogyra insignis & & 0.24 & 5.0 & [46] \\
\hline Spirogyra neglecta & & 0.56 & 5.0 & [47] \\
\hline Caulerpa lentillifera & & 0.13 & 5.0 & [48] \\
\hline Spirogyra sp. & & 0.43 & 5.0 & [49] \\
\hline Cladophora sp. & & 0.22 & 5.0 & [49] \\
\hline Ulva sp. & \multirow{8}{*}{$\mathrm{Cu}(\mathrm{II})$} & 0.75 & 5.0 & [33] \\
\hline Codium vermilara & & 0.26 & 5.0 & [46] \\
\hline Spirogyra insignis & & 0.30 & 4.0 & [46] \\
\hline Spirogyra neglecta & & 1.80 & 4.5 & [47] \\
\hline Ulva fasciata & & 1.14 & 5.5 & [50] \\
\hline Caulerpa lentillifera & & 0.08 & 5.0 & [48] \\
\hline Cladophora sp & & 0.23 & 5.0 & [49] \\
\hline Spirogyra sp & & 0.53 & 5.0 & [51] \\
\hline Ulva sp. & \multirow{8}{*}{$\mathrm{Cd}(\mathrm{II})$} & 0.58 & 5.5 & [33] \\
\hline Chaetomorpha linum & & 0.48 & 5.0 & [52] \\
\hline Codium vermilara & & 0.19 & 6.0 & [46] \\
\hline Spirogyra insignis & & 0.20 & 6.0 & [46] \\
\hline Ulva lactuca & & 0.25 & 5.0 & [53] \\
\hline Oedogonium sp. & & 0.79 & 5.0 & [54] \\
\hline Caulerpa lentillifera & & 0.04 & 5.0 & [48] \\
\hline Spirogyra sp. & & $0.006 \mathrm{a}$ & - & [55] \\
\hline Ulva sp. & \multirow{5}{*}{$\mathrm{Zn}(\mathrm{II})$} & 0.54 & 5.5 & [33] \\
\hline Codium vermilara & & 0.36 & 6 & [46] \\
\hline Spirogyra insignis & & 0.32 & 6 & [46] \\
\hline Caulerpa lentillifera & & 0.04 & 5 & [48] \\
\hline Spirogyras & & $0.02 \mathrm{a}$ & - & [55] \\
\hline Ulva sp. & \multirow{4}{*}{$\mathrm{Ni}(\mathrm{II})$} & 0.29 & 5.5 & [33] \\
\hline Codium vermilara & & 0.22 & 6.0 & [46] \\
\hline Spirogyra insignis & & 0.29 & 6.0 & [46] \\
\hline Ulva lactuca & & 1.14 & 4.5 & [56] \\
\hline \multicolumn{5}{|c|}{ Red Algae } \\
\hline Gracilaria corticata & & 0.26 & 4.5 & [45] \\
\hline Gracilaria canaliculata & & 0.20 & 4.5 & [45] \\
\hline Polysiphonia violacea & & 0.49 & 4.5 & [45] \\
\hline Gracillaria sp. & & 0.45 & 5.0 & [33] \\
\hline Asparagopsis armata & & 0.30 & 4.0 & [46] \\
\hline Jania rubens & & 0.14 & 5.0 & [57] \\
\hline Pterocladia capillacea & & 0.16 & 5.0 & [57] \\
\hline Corallina mediterranea & & 0.31 & 5.0 & [57] \\
\hline Galaxaura oblongata & & 0.42 & 5.0 & [57] \\
\hline Asparagopsis armata & & 0.33 & 5.0 & [46] \\
\hline Chondrus crispus & $\mathrm{Pb}(\mathrm{II})$ & 0.63 & 4.0 & [46] \\
\hline Gelidium & & 0.51 & 5.3 & [58] \\
\hline Gracilaria changii & & 0.23 & 5.0 & [52] \\
\hline Gracilaria edulis & & 0.24 & 5.0 & [52] \\
\hline
\end{tabular}


Table 3. Cont.

\begin{tabular}{|c|c|c|c|c|}
\hline Species of Algae & Metal Ions & qmax (mmol/g) & $\mathrm{pH}$ & References \\
\hline Gracilaria Salicornia & & 0.16 & 5.0 & {$[52]$} \\
\hline Asparagopsis armata & & 0.28 & 6.0 & [46] \\
\hline Ceramium virgatum & & 0.35 & 5.0 & [59] \\
\hline Mastocarpus stellatus & & 0.59 & 6.0 & {$[60]$} \\
\hline Jania rubens & & 0.27 & 5.0 & [57] \\
\hline Corallina mediterranea & & 0.57 & 5.0 & [57] \\
\hline Hypnea valentiae & & 0.15 & 6.0 & [61] \\
\hline \multirow[t]{2}{*}{ Palmaria palmate } & \multirow{8}{*}{$\mathrm{Cr}$} & $0.57(\mathrm{Cr}(\mathrm{III}))$ & $4.5(\mathrm{Cr}$ (III & {$[62]$} \\
\hline & & $0.65(\mathrm{Cr}(\mathrm{VI}))$ & $2(\mathrm{Cr}(\mathrm{VI}))$ & \\
\hline Polysiphonia lanosa & & $0.65(\mathrm{Cr}(\mathrm{III}))$ & $4.5(\mathrm{Cr}(\mathrm{III}))$ & {$[62]$} \\
\hline & & $0.88(\mathrm{Cr}(\mathrm{VI}))$ & $2(\mathrm{Cr}(\mathrm{VI}))$ & \\
\hline Jania rubens & & $0.54(\mathrm{Cr}(\mathrm{III}))$ & $5.0(\mathrm{Cr}(\mathrm{III}))$ & [57] \\
\hline Pterocladia capillacea & & $0.66(\mathrm{Cr}(\mathrm{III}))$ & $5.0(\mathrm{Cr}(\mathrm{III}))$ & [57] \\
\hline Corallina mediterranea & & $1.35(\mathrm{Cr}(\mathrm{III}))$ & $5.0(\mathrm{Cr}(\mathrm{III}))$ & [57] \\
\hline Galaxaura oblongata & & $2.02(\mathrm{Cr}(\mathrm{III}))$ & $5.0(\mathrm{Cr}(\mathrm{III}))$ & [57] \\
\hline Jania rubens & \multirow{4}{*}{$\mathrm{Co}(\mathrm{II})$} & 0.55 & 5.0 & [57] \\
\hline Pterocladia capillacea & & 0.89 & 5.0 & [57] \\
\hline Corallina mediterranea & & 1.29 & 5.0 & {$[57]$} \\
\hline Galaxaura oblongata & & 1.25 & 5.0 & [57] \\
\hline \multicolumn{5}{|c|}{ Brown Algae } \\
\hline Ascophyllum nodosum & \multirow{11}{*}{$\mathrm{Pb}(\mathrm{II})$} & 1.31 & 3.5 & {$[63]$} \\
\hline Fucus vesiculosus & & 1.11 & 3.5 & [63] \\
\hline Sargassum vulgare & & 1.10 & 3.5 & {$[63]$} \\
\hline Sargassum hystrix & & 1.37 & 4.5 & {$[45]$} \\
\hline Sargassum natans & & 1.14 & 4.5 & {$[45]$} \\
\hline Padina pavonia & & 1.04 & 4.5 & [45] \\
\hline Sargassum sp. & & 1.16 & 5.0 & [33] \\
\hline Padina sp. & & 1.25 & 5.0 & {$[33]$} \\
\hline Fucus vesiculosus & & 1.02 & 5.0 & [38] \\
\hline Fucus spiralis & & 0.98 & 3.0 & [46] \\
\hline Ascophyllum nodosu & & 0.86 & 3.0 & [46] \\
\hline Padina sp. & \multirow{10}{*}{$\mathrm{Cu}(\mathrm{II})$} & 1.14 & 5.0 & [33] \\
\hline Sargassum vulgarie & & 0.93 & 4.5 & [64] \\
\hline Sargassum fluitans & & 0.80 & 4.5 & {$[64]$} \\
\hline Sargassum filipendula & & 0.89 & 4.5 & [64] \\
\hline Fucus vesiculosus & & 1.66 & 5.0 & [38] \\
\hline Fucus spiralis & & 1.10 & 4.0 & [46] \\
\hline Ascophyllum nodosum & & 0.91 & 4.0 & [46] \\
\hline Sargassum filipendula & & 1.32 & 4.5 & {$[65]$} \\
\hline Fucus serratus & & 1.60 & 5.5 & [66] \\
\hline Sargassum sp. & & 1.13 & 5.5 & [50] \\
\hline Sargassum sp. & \multirow{14}{*}{$\mathrm{Cd}(\mathrm{II})$} & 0.76 & 5.5 & [33] \\
\hline Padina sp & & 0.75 & 5.5 & [33] \\
\hline Sargassum siliquosum & & 0.73 & 5.0 & [52] \\
\hline Sargassum baccularia & & 0.74 & 5.0 & [52] \\
\hline Padina tetrastomatica & & 0.53 & 5.0 & [52] \\
\hline Sargassum vulgarie & & 0.79 & 4.5 & {$[64]$} \\
\hline Sargassum fluitans & & 0.71 & 4.5 & {$[64]$} \\
\hline Sargassum muticum & & 0.68 & 4.5 & [64] \\
\hline Fucus vesiculosus & & 0.96 & 6.0 & [38] \\
\hline Fucus spiralis & & 1.02 & 6.0 & [46] \\
\hline Ascophyllum nodosum & & 0.78 & 6.0 & [46] \\
\hline Sargassum filipendula & & 1.17 & 5.0 & [67] \\
\hline Bifurcaria bifurcate & & 0.65 & 4.5 & [68] \\
\hline Saccorhiza polyschides & & 0.84 & 4.5 & [68] \\
\hline
\end{tabular}


Table 3. Cont.

\begin{tabular}{|c|c|c|c|c|}
\hline Species of Algae & Metal Ions & qmax (mmol/g) & $\mathrm{pH}$ & References \\
\hline Ascophyllum nodosum & & 0.70 & 4.5 & [68] \\
\hline Laminaria ochroleuca & & 0.56 & 4.5 & [68] \\
\hline Pelvetia caniculata & & 0.66 & 4.5 & [68] \\
\hline Macrocystis pyrifera & & 0.89 & 3.0 & [69] \\
\hline Sargassum sp. & \multirow{6}{*}{$\mathrm{Zn}(\mathrm{II})$} & 0.50 & 5.5 & [33] \\
\hline Padina sp. & & 0.81 & 5.5 & [33] \\
\hline Fucus spiralis & & 0.81 & 6.0 & [46] \\
\hline Ascophyllum nodosum & & 0.64 & 6.0 & [46] \\
\hline Sargassum filipendula & & 0.71 & 5.0 & [67] \\
\hline Macrocystis pyrifera & & 0.91 & 4.0 & [69] \\
\hline Sargassum fluitans & \multirow{14}{*}{$\mathrm{Ni}(\mathrm{II})$} & 0.75 & 3.5 & [63] \\
\hline Ascophyllum nodosum & & 0.69 & 3.5 & [63] \\
\hline Sargassum natans & & 0.41 & 3.5 & [63] \\
\hline Fucus vesiculosus & & 0.39 & 3.5 & [63] \\
\hline Sargassum vulgare & & 0.09 & 3.5 & [63] \\
\hline Sargassum sp & & 0.61 & 5.5 & [33] \\
\hline Padina sp. & & 0.63 & 5.5 & [33] \\
\hline Cystoseria indica & & 0.85 & 6.0 & [70] \\
\hline Nizmuddinia zanardini & & 0.94 & 6.0 & [70] \\
\hline $\begin{array}{c}\text { Sargassum } \\
\text { glaucescensand }\end{array}$ & & 0.94 & 6.0 & [70] \\
\hline Padina australis & & 0.46 & 6.0 & [70] \\
\hline Fucus spiralis & & 0.85 & 6.0 & [46] \\
\hline Ascophyllum nodosum & & 0.73 & 6.0 & [46] \\
\hline Sargassum filipendula & & 1.07 & 4.5 & [65] \\
\hline \multirow[t]{2}{*}{ Fucus vesiculosus } & \multirow{6}{*}{$\mathrm{Cr}$} & $1.21(\mathrm{Cr}(\mathrm{III}))$ & $4.5(\mathrm{Cr}(\mathrm{III}))$ & [62] \\
\hline & & $0.82(\mathrm{Cr}(\mathrm{VI}))$ & $2(\mathrm{Cr}(\mathrm{VI}))$ & \\
\hline \multirow{2}{*}{ Fucus spiralis } & & $1.17(\mathrm{Cr}(\mathrm{III}))$ & $4.5(\mathrm{Cr}(\mathrm{III}))$ & {$[62]$} \\
\hline & & $0.68(\mathrm{Cr}(\mathrm{VI}))$ & $2(\mathrm{Cr}(\mathrm{VI}))$ & \\
\hline Sargassum sp. & & $0.60(\mathrm{Cr}(\mathrm{VI}))$ & $2(\mathrm{Cr}(\mathrm{VI}))$ & [71] \\
\hline Sargassum muticum & & $3.77(\mathrm{Cr}(\mathrm{VI}))$ & $2(\mathrm{Cr}(\mathrm{VI}))$ & [72] \\
\hline
\end{tabular}

$\mathrm{a}=$ Not maximum biosorption value.

Table 3 shows the different species of algae used in the removal of heavy metals. The numbers for metal ion uptake qmax $(\mathrm{mmol} / \mathrm{g})$ for the different species are in the range (0-4), especially the brown alga species (Sargassum muticum), while all uptake occurs between $\mathrm{pH}$ values of (2-6), and $\mathrm{pH}$ influences the dissociation of heavy metals from the solution using different alga species [48,73]. The $\mathrm{pH}$ impacts metal ion uptake, which is a result of the influence of the "functional group on the biomass' cell wall and the metal ions solution" [33]. The polysaccharides present in the cell wall of seaweeds are the most highly metal-binding sites [64].

\subsection{Various Natural Materials Used for Sorption}

In recent years, engineers and scientists have directed much effort towards identifying the most suitable biosorption materials. Among many materials, seaweed has been revealed to be the most suitable and effective natural material. Table 4 shows some of the various other materials that have been used for the removal of metal ions. 
Table 4. Various natural materials used for the removal of metal ions.

\begin{tabular}{|c|c|c|}
\hline Materials Used & Heavy Metals & References \\
\hline Polymers & Fe and $\mathrm{Cr}$ & [74] \\
\hline Sawdust and tree barks & $\mathrm{Hg}, \mathrm{Pb}$, and $\mathrm{Zn}$ & [75] \\
\hline $\begin{array}{l}\text { Electronic waste along with } \\
\text { galvanic wastes }\end{array}$ & $\mathrm{Cu}, \mathrm{Ni}, \mathrm{Mn}, \mathrm{Pb}, \mathrm{Sn}$ & [76] \\
\hline charcoal: & $\mathrm{Cr}(\mathrm{III})$ & [77] \\
\hline Clay & $\mathrm{Cr}(\mathrm{III})$ & [78] \\
\hline Fungi & $\mathrm{Cr}, \mathrm{Fe}$ & [79] \\
\hline Dead biomass & $\mathrm{Cr}$ & [80] \\
\hline Peat moss & $\mathrm{Cr}, \mathrm{Fe}$ & [81] \\
\hline $\begin{array}{l}\text { Peanut shells, Rice husk, } \\
\text { Straw, and walnut cover }\end{array}$ & $\mathrm{Cr}, \mathrm{Cu}, \mathrm{Ni}$ & [82] \\
\hline Cocoa shell & $\mathrm{Al}, \mathrm{Cd}, \mathrm{Co}, \mathrm{Cr}, \mathrm{Cu}, \mathrm{Fe}, \mathrm{Mn}, \mathrm{Ni}, \mathrm{Pb}$, and $\mathrm{Zn}$ & [83] \\
\hline Coconut husk & Cr, As & [82] \\
\hline Caol and fly ashes & $\mathrm{Cr}, \mathrm{Cu}, \mathrm{Ni}$ & [84] \\
\hline Banana pith and peels & $\mathrm{Ni}, \mathrm{Pb}$ & [85] \\
\hline Cassava fiber & $\mathrm{Pb}, \mathrm{Co}$ & [86] \\
\hline Chicken feathers & $\mathrm{Al}$, As & [87] \\
\hline Sheep manure wastes & $\mathrm{Ca}, \mathrm{Cd}$ & [88] \\
\hline Sunflower & $\mathrm{Co}, \mathrm{Cr}$ & [89] \\
\hline Rice byproducts & $\mathrm{Cu}, \mathrm{Fe}$ & [90] \\
\hline Orange peels & $\mathrm{Cu}, \mathrm{Fe}, \mathrm{Hg}$ & [91] \\
\hline Palm kernel fiber & $\mathrm{Fe}, \mathrm{Hg}$ & [82] \\
\hline Grape stalks & $\mathrm{Cr}, \mathrm{Fe}, \mathrm{Hg}$ & [92] \\
\hline
\end{tabular}

As highlighted in Table 4, the use of different biomass (living or dead) for the removal of heavy metals has been studied over the years, and microalgae have stood out among the others. For non-living organisms, the cell surface involves different functional groups like amini, hydroxyl, sulfhydryl, phosphate, sulfate, and carboxyl groups [93]. Sawdust and tree barks are rich in tannin/lignin, and have been studied by Fiset and team [94], as they proved effective in metal adsorption. The tannin is an active species during the metal adsorption (ion exchange) process because of the polyhydroxy polyphenol groups [95]. Lignin, which is extracted from black liquor and is also a waste product of the paper industry, has been considered for the removal of metals $(\mathrm{Hg}, \mathrm{Pb}$, and $\mathrm{Zn})$ [96]. Alcohols, acids, aldehydes, ketones, phenol, hydroxides, and ethers are all polar functional groups of lignin that have varying metal-binding capabilities [97]. Phytoremediation or phytofiltration of metal-contaminated effluents have been tested and proven successful. Some examples of aquatic plants with such ability are Ceratophyllum demersum, Lemna minor, and Myriophyllum spicatum [98]. Cellular components such as amide, imine, imidazol moieties, carboxyl, hydroxyl, sulfate, sulfhydryl, phosphate of these plants have high metalbinding properties, as reported by Gardea and team [99]. Chitin and chitosan have also been used to treat metal ions in wastewater. Chitin, which is the second-most abundant natural biopolymer after cellulose, is commonly found in the exoskeletons of crustaceans and shellfish, while Chitosan is produced by alkaline N-deacetylation of chitin [100]. Similarly, peat moss has been studied based on heavy metal decontamination of wastewater. It is a complex material with both lignin and cellulose as its main constituents, which contain polar functional groups [101]. Plenty of other agricultural waste, such as rice residues, fruit 
and vegetable peels, tea/coffee residues, and coconut husks, have also been used for metal ion retention. Most of the materials have polyhydroxy, polyphenol, carboxylic, and amino groups, which play key roles in the metal adsorption process [83]. Animal bones, clay, human hair, and teeth have all been used to treat metal ions, but have not been effective or efficient when compared with seaweed [102]. In conclusion, the above-discussed natural sorption materials have not been effective either in terms of metal ions removal rate or socio-economic benefit when compared to seaweed.

\section{Sorption Mechanism of Seaweed}

Seaweed is characterized by both physical, biological, and chemical attributes, such as alginate, carrageenan, and photosynthesis features. It can also grow in extreme conditions, in the presence of heavy metals, salinity, and harsh temperatures. Owing to the aforementioned qualities, in addition to its high binding affinity, seaweed is considered a good bioremediation material for treating toxic metal ions in aqueous solutions [103]. Seaweed also has a "hormesis phenomenon feature", which refers to the toxic contamination of algae stimulating further algae growth [104]. Similarly, some cyanobacteria tend to grow in wastewater that is highly polluted with toxic heavy metals; examples of cyanobacteria include; spirogyra, oscillatoria, anabaena, and phormidium [105]. Seaweeds have both antioxidant enzymes and non-enzymatic antioxidants. Antioxidant enzymes include catalase, superoxide dismutase (SOD), ascorbate peroxidase, and reductase, while non-enzymatic antioxidants include glutathione (GHS), cysteine, proline, carotenoids, and ascorbic acid (ASC) [106]. During the sorption process, heavy metals in the seaweed ignite the phytochelatins (PCs) through biosynthesis. These phytochelatins are proteins and thiolrich peptides that can minimize toxic metal ions through interaction [107]. Superoxide dismutase (SOD) performs a defensive role against the superoxide anion, which is exerted by breaking the superoxide anion into hydrogen peroxide and oxygen molecules. The catalase degrades hydrogen peroxide to oxygen and water molecules, while cysteine is the precursor for metallothioneins, phytochelatins (PCs), glutathione (GSH), and other sulfur-related compounds. [108]. The reduction of free radicals and reactive oxygen species (ROS) is performed by both glutathione (GSH) and ascorbic acid (ASC), which are endogenous antioxidants that are synthesized by seaweed [109]. Additionally, seaweed produces a high level of ascorbic acid (ASC) as "hydrophilic redox buffer", which protects cytosol against the threat of oxidation. Similarly, the seaweed is protected by glutathione (GSH) by enabling phytochelatins (PCs), scavenging free radicals, and ascorbic acid (ASC) synthesis alongside the restoration of substrate for other antioxidants [106,107]. The chemistry involved in the interaction between the biomass (seaweed) and the metal ions is shown in Figures 5 and 6, respectively.

As shown in Figure 5, the removal mechanism of heavy metals is performed in two folds. These two folds include biosorption, which is the "rapid extracellular passive adsorption", and the latter is bioaccumulation, which is the "slow intracellular positive diffusion and accumulation". Seaweeds' cell walls are made up of cellulose and alginate (polysaccharides) and lipids, while the organic protein offers amino, phosphate, hydroxyl, thiol-rich, and carboxyl (functional groups), which all possess good ability to bind metal ions [105]. Additionally, the cell wall is composed of laminarin, deprotonated sulphate, and monomeric alcohols capable of attracting both cationic and anionic species of metal ions [110]. Adsorption on the surface of seaweed occurs rapidly when compared to inside the seaweed. On the surface, adsorption takes place through ion exchange with the cell wall and covalent bonding with the ionized cell wall, resulting in "seaweed exopolysaccharides". Conversely, adsorption is slow inside, and phytochelatins, GSH, and metal transporter play a leading role in the binding of metal ions. This accumulation of metal ions inside is carried across the cell membrane to the cytoplasm before diffusion $[110,111]$.

According to Figure 6, the biochemical constituent of seaweed is responsible for the sequestration of metal ions, which are composed of alginate and fucoidan in the cell wall. The cell wall of microalgae is made up of a fibrillary skeleton (cellulose) and 
an amorphous embedded matrix (alginate) [5]. The cell wall of brown algae contain sulfated polysaccharides, while in red algae, galactans are found, and green algae, hydroxylproline [46].

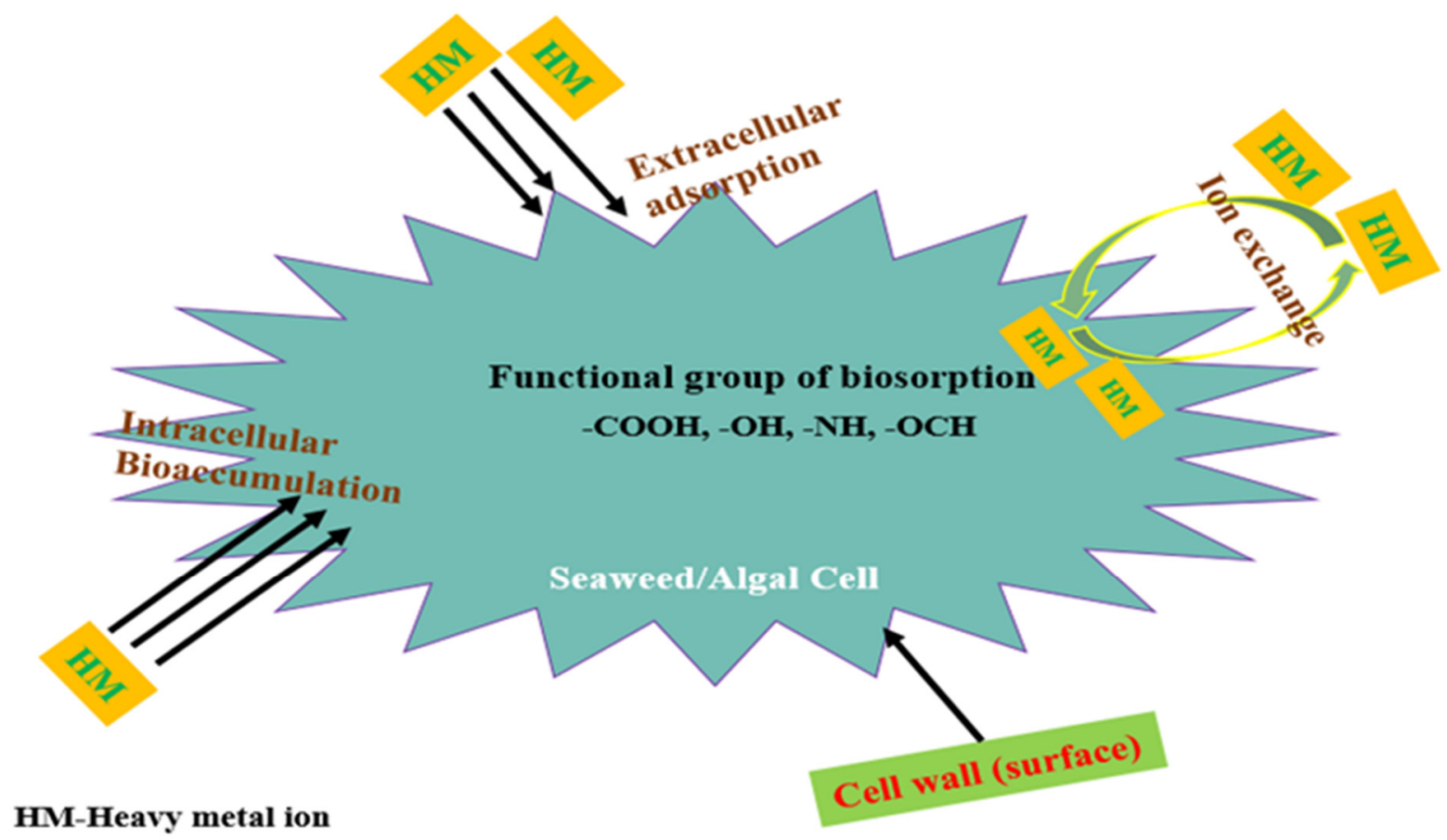

Figure 5. Mechanism of metal ion interaction with seaweed.

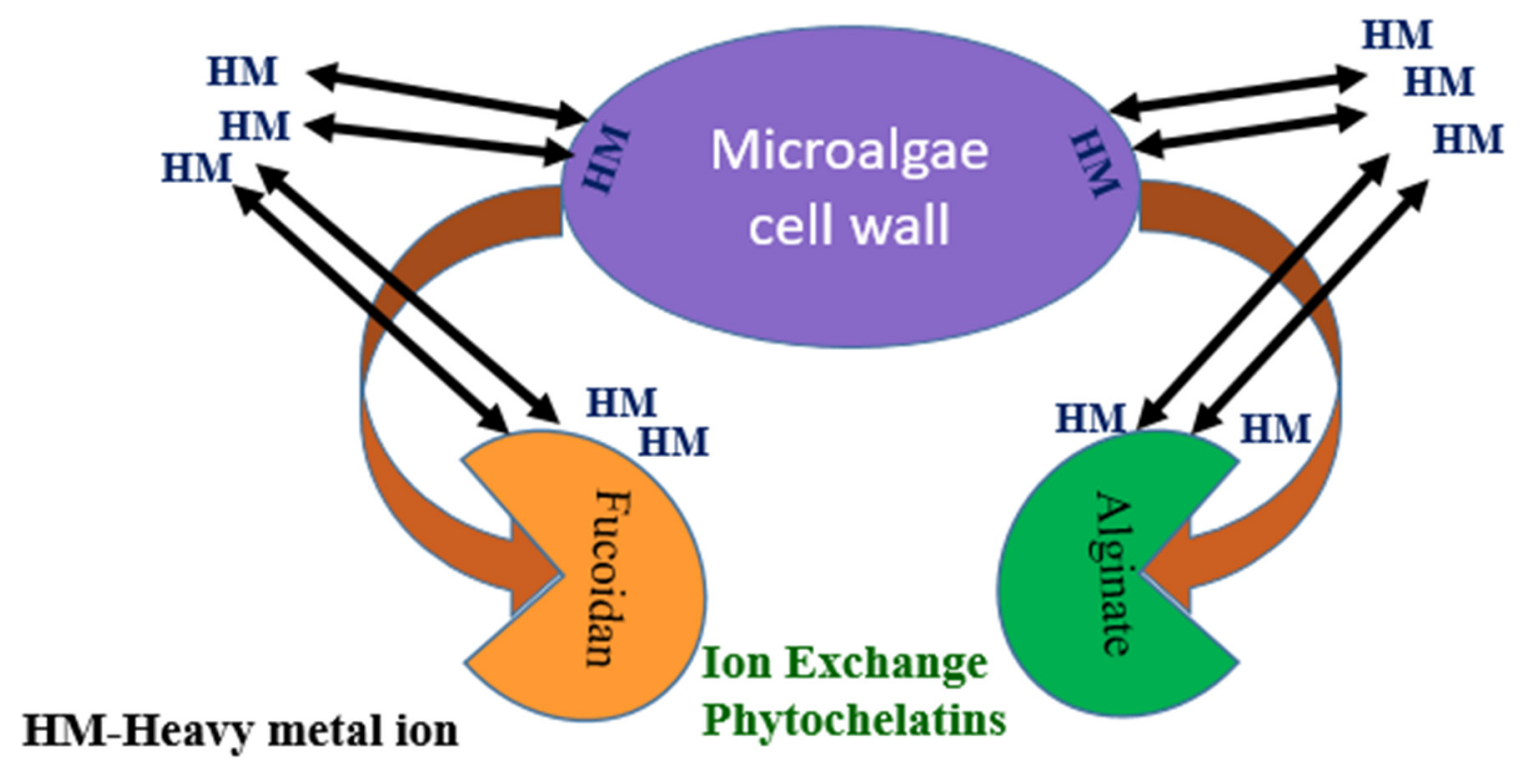

Figure 6. Interaction between metal ions and algal biomass.

\section{Conclusions}

The usage of seaweed as a sorption material has attracted the attention of many researchers in recent times. Seaweed's relevance is not only restricted to the treatment of heavy metals; it is a precious food that is prominent in basic balanced diets. Considering the current state of heavy metal pollution in our environment, seaweed has been proven to be an excellent, cheap, effective, abundantly available, eco-friendly, and efficient material for remediating the environment when compared to other natural sorption materials. This 
multi-faceted and multi-dimensional seaweed has the potential to heal the world from various environmental menaces. It is evidence that seaweed could be economically prudent both for industrial and environmental uses. As seaweeds are among the most fascinating and resourceful species, more exploration is needed to reap the benefits of these unique species. For sorption purposes, seaweed has been proven to be a good biosorption material with high metal ion uptake (qmax $(\mathrm{mmol} / \mathrm{g})$ ) within the range (0-4). The brown alga (Sargassum muticum) stands out efficiently at a $\mathrm{pH}$ value of 2 when compared to other natural sorption materials. The main biochemical interaction between the algae and the metal ions depends on the cell wall, with polysaccharides, lipids, and other organic proteins being the components that play the main roles during the sorption process. In conclusion, the sorption of metal ions using seaweed, especially brown algae, presents a solution that is more reliable, cheaper, and possesses more effective sorption ability than other natural sorption materials previously studied.

Author Contributions: Conceptualization-E.H.F.J., B.B.; Funding acquisition-B.B.; MethodologyE.H.F.J., B.B., X.X.; Resources-B.B.; Software-E.H.F.J; Supervision-B.B., X.X.; Validation-X.X.; Writingoriginal draft-E.H.F.J.; Writing—review \& editing-E.H.F.J., B.B., X.X.; Project administration-B.B. All authors have read and agreed to the published version of the manuscript.

Funding: This work was funded by the Natural Science Basic Research Program of Shaanxi (Program No. 2021SF-497), and the Fundamental Research Funds for Central Universities (CHD 300102291403).

Institutional Review Board Statement: Not applicable.

Informed Consent Statement: Not applicable.

Data Availability Statement: Not applicable.

Conflicts of Interest: This work has no conflict of interest.

\section{References}

1. Ajjabi, L.C.; Chouba, L. Biosorption of $\mathrm{Cu}^{2+}$ and $\mathrm{Zn}^{2+}$ from aqueous solutions by dried marine green macroalga Chaetomorpha linum. J. Environ. Manag. 2009, 90, 3485-3489. [CrossRef]

2. Bulut, Y.; Baysal, Z. Removal of $\mathrm{Pb}$ (II) from wastewater using wheat bran. J. Environ. Manag. 2006, 78, 107-113. [CrossRef]

3. Al-Rub, F.; El-Naas, M.; Benyahia, F.; Ashour, I. Biosorption of nickel on blank alginate beads, free and immobilized algal cells. Process. Biochem. 2004, 39, 1767-1773. [CrossRef]

4. Argun, M.E.; Dursun, S.; Ozdemir, C.; Karatas, M. Heavy metal adsorption by modified oak sawdust: Thermodynamics and kinetics. J. Hazard. Mater. 2007, 141, 77-85. [CrossRef] [PubMed]

5. Davis, T.A.; Volesky, B.; Mucci, A. A review of the biochemistry of heavy metal biosorption by brown algae. Water Res. 2003, 37, 4311-4330. [CrossRef]

6. He, J.; Chen, J.P. A comprehensive review on biosorption of heavy metals by algal biomass: Materials, performances, chemistry, and modeling simulation tools. Bioresour. Technol. 2014, 160, 67-78. [CrossRef] [PubMed]

7. Romera, D.E.; González, F.; Ballester, A.; Blázquez, M.L.; Muñoz, J.A. Biosorption with Algae: A Statistical Review. Crit. Rev. Biotechnol. 2006, 26, 223-235. [CrossRef]

8. Gupta, V.K.; Nayak, A.; Agarwal, S. Bioadsorbents for remediation of heavy metals: Current status and their future prospects. Environ. Eng. Res. 2015, 20, 1-18. [CrossRef]

9. Abrar, M.; Hussain, Z.; Akif, M.; Sok, K.; Muhammad, A.; Khan, A.; Khan, M. Textile effluents and their contribution towards aquatic pollution in the Kabul River (Pakistan). J. Chem. Soc. Pak. 2011, $24,106$.

10. Afzal, M.S.; Ashraf, A.; Nabeel, M. Characterization of industrial effluents and groundwater of Hattar industrial estate, Haripur. Adv. Agric. Environ. Sci. Open Access (AAEOA) 2018, 1, 70-77.

11. Yang, X.E.; Jin, X.F.; Feng, Y.; Islam, E. Molecular mechanisms and genetic basis of heavy metal toler-ance/hyperaccumulation in plants. J. Integr. Plant Biol. 2005, 47, 1025-1035. [CrossRef]

12. Nriagu, J.O. A global assessment of natural sources of atmospheric trace metals. Nat. Cell Biol. 1989, 338, 47-49. [CrossRef]

13. Yang, J.; Wei, W.; Pi, S.; Ma, F.; Li, A.; Wu, D.; Xing, J. Competitive adsorption of heavy metals by extracellular polymeric substances extracted from Klebsiella sp. J1. Bioresour. Technol. 2015, 196, 533-539. [CrossRef] [PubMed]

14. Duruibe, J.O.; Ogwuegbu, M.; Egwurugwu, J. Heavy metal pollution and human biotoxic effects. Int. J. Phys. Sci. 2007, 2, 112-118.

15. Bravo, S.; Amorós, J.; Pérez-de-los-Reyes, C.; García, F.; Moreno, M.; Sánchez-Ormeño, M.; Higueras, P. Influence of the soil pH in the uptake and bioaccumulation of heavy metals ( $\mathrm{Fe}, \mathrm{Zn}, \mathrm{Cu}, \mathrm{Pb}$ and $\mathrm{Mn}$ ) and other elements (Ca, $\mathrm{K}, \mathrm{Al}$, Sr and $\mathrm{Ba})$ in vine leaves, Castilla-La Mancha (Spain). J. Geochem. Explor. 2017, 174, 79-83. [CrossRef] 
16. Tchounwou, P.B.; Yedjou, C.G.; Patlolla, A.K.; Sutton, D.J. Heavy Metal Toxicity and the Environment. Mol. Clin. Environ. Toxicol. 2012, 101, 133-164. [CrossRef]

17. Jaishankar, M.; Tseten, T.; Anbalagan, N.; Mathew, B.B.; Beeregowda, K.N. Toxicity, mechanism and health effects of some heavy metals. Interdiscip. Toxicol. 2014, 7, 60-72. [CrossRef]

18. Prasher, P.; Mudila, H.; Sharma, M. Biosorption and Bioaccumulation of Pollutants for Environmental Remediation. In Microorganisms for Sustainability; Springer International Publishing: Singapore, 2021; pp. 379-405.

19. World Health Organization. Trace Elements in Human Nutrition and Health; World Health Organization: Geneva, Swizerland, 1996.

20. World Health Organization. Guidelines for Drinking-Water Quality, First Addendum to the Fourth Edition; World Health Organization: Geneva, Swizerland, 2017.

21. United States Environmental Protection Agency (USEPA). Code of Federal Regulations-2003, Title 40-PART 141-NATIONAL PRIMARY DRINKING WATER REGULATIONS, Subpart B-Maximum Contaminant Levels. Available online: https://www. epa.gov / sites / default / files/2015-11/documents/howepargulates_cfr-2003-title40-vol20-part141_0.pdf (accessed on 30 October 2021).

22. European Union. Directive (EU) 2020/2184 of the European Parliament and of the Council of 16 December 2020 on the Quality of Water Intended for Human Consumption. Off. J. Eur. Union 2020, 435, 1-62.

23. The National Standards of the People's Republic of China. Environmental Quality Standards for Surface Water. Available online: http:/ / english.mee.gov.cn/SOE/soechina1997/water/standard.htm (accessed on 30 October 2021).

24. Water, E.A.W. The Water Supply (Water Quality) Regulations 2016, PART 13 Amendments and Revocations. Available online: https://www.legislation.gov.uk/uksi/2016/614/pdfs/uksi_20160614_en.pdf (accessed on 30 October 2021).

25. Hayashi, K.; Rivai, I.F.; Herawati, N.; Suzuki, S.; Koyama, H. Cadmium, Copper, and Zinc Levels in Rice and Soil of Japan, Indonesia, and China by Soil Type. Bull. Environ. Contam. Toxicol. 2000, 64, 33-39. [CrossRef]

26. He, Z.L.; Yang, X.E.; Stoffella, P.J. Trace elements in agroecosystems and impacts on the environment. J. Trace Elem. Med. Biol. 2005, 19, 125-140. [CrossRef]

27. Mahadevan, K. Seaweeds: A sustainable food source. In Seaweed Sustainability; Elsevier BV: Manchester, UK, 2015; pp. 347-364.

28. Collins, K.G. An investigation of the prebiotic potential and gut health benefits of Irish seaweeds. Univ. Coll. Cork 2017, 371, 31-35.

29. Gade, R.; Tulasi, M.S.; Bhai, V.A. Seaweeds: A novel biomaterial. Int. J. Pharm. Pharm. Sci. 2013, 5, 975-1491.

30. Harbo, J.R.; Harris, J.W. Heritability in Honey Bees (Hymenoptera: Apidae) of Characteristics Associated with Resistance to Varroa jacobsoni(Mesostigmata: Varroidae). J. Econ. Entomol. 1999, 92, 261-265. [CrossRef]

31. Bittner, L.; Payri, C.; Couloux, A.; Cruaud, C.; De Reviers, B.; Rousseau, F. Molecular phylogeny of the Dictyotales and their position within the Phaeophyceae, based on nuclear, plastid and mitochondrial DNA sequence data. Mol. Phylogenetics Evol. 2008, 49, 211-226. [CrossRef]

32. Yalçın, S.; Sezer, S.; Apak, R. Characterization and lead (II), cadmium (II), nickel (II) biosorption of dried marine brown macro algae Cystoseira barbata. Environ. Sci. Pollut. Res. 2012, 19, 3118-3125. [CrossRef] [PubMed]

33. Sheng, P.X.; Ting, Y.-P.; Chen, J.P.; Hong, L. Sorption of lead, copper, cadmium, zinc, and nickel by marine algal biomass: Characterization of biosorptive capacity and investigation of mechanisms. J. Colloid Interface Sci. 2004, 275, 131-141. [CrossRef]

34. Adamu, C.; Nganje, T.; Edet, A. Heavy metal contamination and health risk assessment associated with abandoned barite mines in Cross River State, southeastern Nigeria. Environ. Nanotechnol. Monit. Manag. 2015, 3, 10-21. [CrossRef]

35. Badruddoza, A.Z.M.; Shawon, Z.B.Z.; Tay, W.J.D.; Hidajat, K.; Uddin, M.S. Fe3O4/cyclodextrin polymer nanocom-posites for selective heavy metals removal from industrial wastewater. Carbohydr. Polymers 2013, 91, 322-332. [CrossRef]

36. Turan, N.G.; Mesci, B. Use of Pistachio Shells as an Adsorbent for the Removal of Zinc(II) Ion. CLEAN-Soil Air Water 2011, 39, 475-481. [CrossRef]

37. Pozdniakova, T.A.; Mazur, L.P.; Boaventura, R.A.; Vilar, V.J. Brown macro-algae as natural cation exchangers for the treatment of zinc containing wastewaters generated in the galvanizing process. J. Clean. Prod. 2016, 119, 38-49. [CrossRef]

38. Mata, Y.; Blázquez, M.; Ballester, A.; González, F.; Muñoz, J.A. Characterization of the biosorption of cadmium, lead and copper with the brown alga Fucus vesiculosus. J. Hazard. Mater. 2008, 158, 316-323. [CrossRef] [PubMed]

39. Michalak, I.; Chojnacka, K. Interactions of metal cations with anionic groups on the cell wall of the macroalga Vaucheria sp. Eng. Life Sci. 2010, 10, 209-217. [CrossRef]

40. Gupta, V.; Rastogi, A. Biosorption of lead from aqueous solutions by green algae Spirogyra species: Kinetics and equilibrium studies. J. Hazard. Mater. 2008, 152, 407-414. [CrossRef]

41. Mehta, S.K.; Gaur, J.P. Use of Algae for Removing Heavy Metal Ions From Wastewater: Progress and Prospects. Crit. Rev. Biotechnol. 2005, 25, 113-152. [CrossRef]

42. Errasquín, E.L.; Vázquez, C. Tolerance and uptake of heavy metals by Trichoderma atroviride isolated from sludge. Chemosphere 2003, 50, 137-143. [CrossRef]

43. Bishnoi, N.R.; Kumar, R.; Kumar, S.; Rani, S. Biosorption of Cr(III) from aqueous solution using algal biomass spirogyra spp. J. Hazard. Mater. 2007, 145, 142-147. [CrossRef]

44. Ebrahimi, B.; Shojaosadati, S.; Ranaie, S.; Mousavi, S. Optimization and evaluation of acetylcholine esterase immobilization on ceramic packing using response surface methodology. Process. Biochem. 2010, 45, 81-87. [CrossRef] 
45. Jalali, R.; Ghafourian, H.; Asef, Y.; Davarpanah, S.; Sepehr, S. Removal and recovery of lead using nonliving biomass of marine algae. J. Hazard. Mater. 2002, 92, 253-262. [CrossRef]

46. Romera, E.; González, F.; Ballester, A.; Blázquez, M.; Munoz, J. Comparative study of biosorption of heavy metals using different types of algae. Bioresour. Technol. 2007, 98, 3344-3353. [CrossRef] [PubMed]

47. Singh, R.K.; Chavan, S.L.; Sapkale, P.H. Heavy Metal Concentrations in Water, Sediments and Body Tissues of Red Worm (Tubifex spp.) Collected from Natural Habitats in Mumbai, India. Environ. Monit. Assess. 2006, 129, 471-481. [CrossRef]

48. Pavasant, P.; Apiratikul, R.; Sungkhum, V.; Suthiparinyanont, P.; Wattanachira, S.; Marhaba, T.F. Biosorption of Cu2+, Cd2+, Pb2+, and Zn2+ using dried marine green macroalga Caulerpa lentillifera. Bioresour. Technol. 2006, 97, 2321-2329. [CrossRef]

49. Lee, Y.-C.; Chang, S.-P. The biosorption of heavy metals from aqueous solution by Spirogyra and Cladophora filamentous macroalgae. Bioresour. Technol. 2011, 102, 5297-5304. [CrossRef]

50. Karthikeyan, S.; Balasubramanian, R.; Iyer, C. Evaluation of the marine algae Ulva fasciata and Sargassum sp. for the biosorption of $\mathrm{Cu}(\mathrm{II})$ from aqueous solutions. Bioresour. Technol. 2007, 98, 452-455. [CrossRef]

51. Rajfur, M.; Kłos, A.; Wacławek, M. Sorption of copper(II) ions in the biomass of alga Spirogyra sp. Bioelectrochemistry 2012, 87, 65-70. [CrossRef]

52. Hashim, M.; Chu, K. Biosorption of cadmium by brown, green, and red seaweeds. Chem. Eng. J. 2004, 97, 249-255. [CrossRef]

53. Sari, A.; Tuzen, M. Biosorption of $\mathrm{Pb}(\mathrm{II})$ and $\mathrm{Cd}(\mathrm{II})$ from aqueous solution using green alga (Ulva lactuca) biomass. J. Hazard. Mater. 2008, 152, 302-308. [CrossRef] [PubMed]

54. Gupta, V.; Rastogi, A. Equilibrium and kinetic modelling of cadmium (II) biosorption by nonliving algal biomass Oedogonium sp. from aqueous phase. J. Hazard. Mater. 2008, 153, 759-766. [CrossRef]

55. Rajfur, M.; Kłos, A.; Wacławek, M. Sorption properties of algae Spirogyra sp. and their use for determination of heavy metal ions concentrations in surface water. Bioelectrochemistry 2010, 80, 81-86. [CrossRef]

56. Zakhama, S.; Dhaouadi, H.; M'Henni, F. Nonlinear modelisation of heavy metal removal from aqueous solution using Ulva lactuca algae. Bioresour. Technol. 2011, 102, 786-796. [CrossRef] [PubMed]

57. Ibrahim, W.M. Biosorption of heavy metal ions from aqueous solution by red macroalgae. J. Hazard. Mater. 2011, 192, 1827-1835. [CrossRef]

58. Vilar, V.J.; Botelho, C.M.; Boaventura, R.A. Copper removal by algae Gelidium, agar extraction algal waste and granu-lated algal waste: Kinetics and equilibrium. Bioresour. Technol. 2008, 99, 750-762. [CrossRef] [PubMed]

59. Sari, A.; Tuzen, M. Biosorption of cadmium(II) from aqueous solution by red algae (Ceramium virgatum): Equilibrium, kinetic and thermodynamic studies. J. Hazard. Mater. 2008, 157, 448-454. [CrossRef] [PubMed]

60. Herrero, R.; Lodeiro, P.; García-Casal, L.J.; Vilariño, T.; Rey-Castro, C.; David, C.; Rodríguez, P. Full description of copper uptake by algal biomass combining an equilibrium NICA model with a kinetic intraparticle diffusion driving force approach. Bioresour. Technol. 2011, 102, 2990-2997. [CrossRef]

61. Rathinam, A.; Maharshi, B.; Janardhanan, S.K.; Jonnalagadda, R.R.; Nair, B.U. Biosorption of cadmium metal ion from simulated wastewaters using Hypnea valentiae biomass: A kinetic and thermodynamic study. Bioresour. Technol. 2010, 101, 1466-1470. [CrossRef] [PubMed]

62. Murphy, V.; Hughes, H.; McLoughlin, P. Comparative study of chromium biosorption by red, green and brown seaweed biomass. Chemosphere 2008, 70, 1128-1134. [CrossRef]

63. Holan, Z.R.; Volesky, B. Biosorption of lead and nickel by biomass of marine algae. Biotechnol. Bioeng. 1994, 43, 1001-1009. [CrossRef] [PubMed]

64. Davis, T.; Volesky, B.; Vieira, R. Sargassum seaweed as biosorbent for heavy metals. Water Res. 2000, 34, 4270-4278. [CrossRef]

65. Kleinübing, S.; Silva, E.; da Silva, M.G.C.; Guibal, E. Equilibrium of Cu(II) and Ni(II) biosorption by marine alga Sargassum filipendula in a dynamic system: Competitiveness and selectivity. Bioresour. Technol. 2011, 102, 4610-4617. [CrossRef]

66. Ahmady-Asbchin, S.; Andres, Y.; Gerente, C.; Le Cloirec, P. Biosorption of $\mathrm{Cu}$ (II) from aqueous solution by Fucus serratus: Surface characterization and sorption mechanisms. Bioresour. Technol. 2008, 99, 6150-6155. [CrossRef] [PubMed]

67. Luna, A.; Costa, A.; Da Costa, A.C.A.; Henriques, C. Competitive biosorption of cadmium(II) and zinc(II) ions from binary systems by Sargassum filipendula. Bioresour. Technol. 2010, 101, 5104-5111. [CrossRef]

68. Lodeiro, P.; Cordero, B.; Barriada, J.L.; Herrero, R.; de Vicente, M.S. Biosorption of cadmium by biomass of brown marine macroalgae. Bioresour. Technol. 2005, 96, 1796-1803. [CrossRef]

69. Cazón, J.P.; Bernardelli, C.; Viera, M.; Donati, E.; Guibal, E. Zinc and cadmium biosorption by untreated and calci-um-treated Macrocystis pyrifera in a batch system. Bioresour. Technol. 2012, 116, 195-203. [CrossRef]

70. Pahlavanzadeh, H.; Keshtkar, A.; Safdari, J.; Abadi, Z. Biosorption of nickel(II) from aqueous solution by brown algae: Equilibrium, dynamic and thermodynamic studies. J. Hazard. Mater. 2010, 175, 304-310. [CrossRef]

71. Yang, L.; Chen, J.P. Biosorption of hexavalent chromium onto raw and chemically modified Sargassum sp. Bioresour. Technol. 2008, 99, 297-307. [CrossRef] [PubMed]

72. Bermúdez, Y.G.; Rico, I.L.R.; Guibal, E.; de Hoces, M.C.; Martín-Lara, M.Á. Biosorption of hexavalent chromium from aqueous solution by Sargassum muticum brown alga. Application of statistical design for process optimization. Chem. Eng. J. 2012, 183, 68-76. [CrossRef]

73. Guo, D.; Mitchell, R.J.; Withington, J.M.; Fan, P.-P.; Hendricks, J.J. Endogenous and exogenous controls of root life span, mortality and nitrogen flux in a longleaf pine forest: Root branch order predominates. J. Ecol. 2008, 96, 737-745. [CrossRef] 
74. Pathe, P.P.; Nandy, T.; Kaul, S.N.; Szpyrokwicz, L. Chromium recovery from chrome tan wastewater. Int. J. Environ. Stud. 1996, 51, 125-145. [CrossRef]

75. Lichtfouse, E.; Elbisser, B. 2nd European Meeting on Environmental Chemistry. In Proceedings of the 2nd European Meeting on Environmental Chemistry, Dijon, France, 12-15 December 2001; p. 273.

76. Vegliò, F.; Quaresima, R.; Fornari, P.; Ubaldini, S. Recovery of valuable metals from electronic and galvanic industrial wastes by leaching and electrowinning. Waste Manag. 2003, 23, 245-252. [CrossRef]

77. Dahbi, S.; Azzi, M.; Saib, N.; De la Guardia, M.; Faure, R.; Durand, R. Removal of trivalent chromium from tannery waste waters using bone charcoal. Anal. Bioanal. Chem. 2002, 374, 540-546. [CrossRef]

78. Park, S.-J.; Jung, W.-Y. Removal of chromium by activated carbon fibers plated with copper metal. Carbon Lett. 2001, 2, 15-21.

79. Bai, R.; Abraham, T. Studies on enhancement of $\mathrm{Cr}(\mathrm{VI})$ biosorption by chemically modified biomass of Rhizopus nigricans. Water Res. 2002, 36, 1224-1236. [CrossRef]

80. Chong, K.H.; Volesky, B. Metal biosorption equilibria in a ternary system. Biotechnol. Bioeng. 1996, 49, 629-638. [CrossRef]

81. Lee, S.-J.; Park, J.H.; Ahn, Y.; Chung, J.W. Comparison of Heavy Metal Adsorption by Peat Moss and Peat Moss-Derived Biochar Produced Under Different Carbonization Conditions. Water Air Soil Pollut. 2015, 226, 9. [CrossRef]

82. Ofomaja, A.; Ho, Y.-S. Effect of pH on cadmium biosorption by coconut copra meal. J. Hazard. Mater. 2007, 139, 356-362. [CrossRef]

83. Meunier, N.; Laroulandie, J.; Blais, J.; Tyagi, R. Cocoa shells for heavy metal removal from acidic solutions. Bioresour. Technol. 2003, 90, 255-263. [CrossRef]

84. Tan, L.C.; Choa, V.; Tay, J.H. The Influence of pH on Mobility of Heavy Metals from Municipal Solid Waste Incinerator Fly Ash. Environ. Monit. Assess. 1997, 44, 275-284. [CrossRef]

85. Foday Jr, E.H.; Ramli, N.A.S.; Ismail, H.N.; Malik, N.A.; Basri, H.F.; Aziz, F.S.A.; Nor, N.S.M.; Jumhat, F. Municipal solid waste characteristics in Taman Universiti, Skudai, Johore, Malaysia. J. Adv. Res. Des. 2017, 38, 13-20.

86. Abia, A.; Asuquo, E. Lead (II) and nickel (II) adsorption kinetics from aqueous metal solutions using chemically modified and unmodified agricultural adsorbents. Afr. J. Biotechnol. 2006, 5, 1475-1482.

87. Al-Asheh, S.; Banat, F.; Al-Rousan, D. Adsorption of Copper, Zinc and Nickel Ions from Single and Binary Metal Ion Mixtures on to Chicken Feathers. Adsorpt. Sci. Technol. 2002, 20, 849-864. [CrossRef]

88. Abu Al-Rub, F.A.; Kandah, M.; Al-Dabaybeh, N. Competitive Adsorption of Nickel and Cadmium on Sheep Manure Wastes: Experimental and Prediction Studies. Sep. Sci. Technol. 2003, 38, 483-497. [CrossRef]

89. Özdemir, N.; Horn, R.; Friedt, W. Construction and characterization of a BAC library for sunflower (Helianthus annuus L.). Euphytica 2004, 138, 177-183. [CrossRef]

90. Ajmal, M.; Rao, R.A.K.; Anwar, S.; Ahmad, J.; Ahmad, R. Adsorption studies on rice husk: Removal and recovery of Cd(II) from wastewater. Bioresour. Technol. 2003, 86, 147-149. [CrossRef]

91. Ajmal, M.; Rao, R.A.K.; Ahmad, R.; Ahmad, J. Adsorption studies on Citrus reticulata (fruit peel of orange): Removal and recovery of $\mathrm{Ni}(\mathrm{II})$ from electroplating wastewater. J. Hazard. Mater. 2000, 79, 117-131. [CrossRef]

92. Fiol, N.; Villaescusa, I.; Martínez, M.; Miralles, N.; Poch, J.; Serarols, J. Sorption of Pb (II), Ni (II), Cu (II) and Cd (II) from aqueous solution by olive stone waste. Sep. Purif. Technol. 2006, 50, 132-140. [CrossRef]

93. Kapoor, A.; Viraraghavan, T. Heavy metal biosorption sites in Aspergillus niger. Bioresour. Technol. 1997, 61, 221-227. [CrossRef]

94. Vaishya, R.; Prasad, S. Adsorption of copper (II) on sawdust. Indian J. Environ. Prot. 1991, 11, $284-289$.

95. Vázquez, G.; Antorrena, G.; González-Álvarez, J.; Doval, M. Adsorption of heavy metal ions by chemically modified Pinus pinaster bark. Bioresour. Technol. 1994, 48, 251-255. [CrossRef]

96. Srivastava, S.K.; Gupta, V.K.; Mohan, D. Removal of Lead and Chromium by Activated Slag-A Blast-Furnace Waste. J. Environ. Eng. 1997, 123, 461-468. [CrossRef]

97. Bailey, S.E.; Olin, T.J.; Bricka, R.; Adrian, D. A review of potentially low-cost sorbents for heavy metals. Water Res. 1999, 33, 2469-2479. [CrossRef]

98. Keskinkan, O.; Goksu, M.; Basibuyuk, M.; Forster, C. Heavy metal adsorption properties of a submerged aquatic plant (Ceratophyllum demersum). Bioresour. Technol. 2004, 92, 197-200. [CrossRef]

99. Gardea-Torresdey, J.; Peralta-Videa, J.; Montes, M.; de la Rosa, G.; Corral-Diaz, B. Bioaccumulation of cadmium, chromium and copper by Convolvulus arvensis L.: Impact on plant growth and uptake of nutritional elements. Bioresour. Technol. 2004, 92, 229-235. [CrossRef]

100. Dumitriu, S. Polysaccharides as Biomaterials. In Polymeric Biomaterials, Revised and Expanded; CRC Press: New York, NY, USA, 2001; pp. 15-76.

101. Brown, P.; Gill, S.; Allen, S.J. Determination of optimal peat type to potentially capture copper and cadmium from solu-tion. Water Environ. Res. 2001, 73, 351-362. [CrossRef]

102. Celis, R.; Hermosín, M.C.; Cornejo, J. Heavy Metal Adsorption by Functionalized Clays. Environ. Sci. Technol. 2000, 34, 4593-4599. [CrossRef]

103. Cameron, H.; Mata, M.T.; Riquelme, C. The effect of heavy metals on the viability of Tetraselmis marina AC16-MESO and an evaluation of the potential use of this microalga in bioremediation. PeerJ 2018, 6, e5295. [CrossRef] 
104. Sun, K.; Tang, J.; Gong, Y.; Zhang, H. Characterization of potassium hydroxide (KOH) modified hydrochars from different feedstocks for enhanced removal of heavy metals from water. Environ. Sci. Pollut. Res. 2015, 22, 16640-16651. [CrossRef] [PubMed]

105. Priatni, S.; Kosasih, W.; A Budiwati, T.; Ratnaningrum, D. Production of peptone from boso fish (Oxyeleotris marmorata) for bacterial growth medium. In IOP Conference Series: Earth and Environmental Science; IOP Publishing: Tangerang, Indonesia, 2017; p. 012009.

106. Upadhyay, A.; Singh, N.; Singh, R.; Rai, U. Amelioration of arsenic toxicity in rice: Comparative effect of inoculation of Chlorella vulgaris and Nannochloropsis sp. on growth, biochemical changes and arsenic uptake. Ecotoxicol. Environ. Saf. 2016, 124, 68-73. [CrossRef]

107. Gómez-Jacinto, V.; García-Barrera, T.; Gómez-Ariza, J.L.; Garbayo-Nores, I.; Vílchez-Lobato, C. Elucidation of the defence mechanism in microalgae Chlorella sorokiniana under mercury exposure. Identification of $\mathrm{Hg}-$ phytochelatins. Chemi-Co-Biol. Interact. 2015, 238, 82-90. [CrossRef]

108. Balaji, S.; Kalaivani, T.; Sushma, B.; Pillai, C.V.; Shalini, M.; Rajasekaran, C. Characterization of sorption sites and differ-ential stress response of microalgae isolates against tannery effluents from Ranipet industrial area-An application towards phycoremediation. Int. J. Phytoremediat. 2016, 18, 747-753. [CrossRef]

109. Devars, S.; Avilés, C.; Cervantes, C.; Moreno-Sánchez, R. Mercury uptake and removal by Euglena gracilis. Arch. Microbiol. 2000, 174, 175-180. [CrossRef] [PubMed]

110. Pradhan, P.; Costa, L.; Rybski, D.; Lucht, W.; Kropp, J.P. A systematic study of sustainable development goal (SDG) in-teractions. Earth's Future 2017, 5, 1169-1179. [CrossRef]

111. Ibuot, A.; Dean, A.P.; McIntosh, O.A.; Pittman, J.K. Metal bioremediation by CrMTP4 over-expressing Chlamydomonas reinhardtii in comparison to natural wastewater-tolerant microalgae strains. Algal Res. 2017, 24, 89-96. [CrossRef] 